\title{
IMPLEMENTASI DAN EVALUASI SISTEM INFORMASI AKADEMIK SEKOLAH DASAR NEGERI 6 DENGAN PENDEKATAN USER EXPERIENCE (UX)
}

\author{
Siti Yuliyanti*1, Dede Abdul Rasid*2 \\ Sekolah Tinggi Manajemen dan Informatika \\ Bandung [STMIK BANDUNG] \\ sitiyuliyanti.stmikbandung@gmail.com, ${ }^{2}$ studentofipa@gmail.com
}

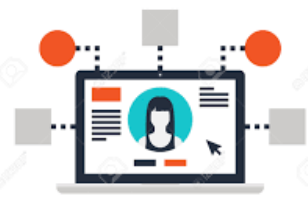

USER EXPERIENCE

\begin{abstract}
ABSTRAK
Banyaknya sistem informasi yang dibangun untuk sekolah, menjadi permasalahan ketika fungsionalitas dari sistem kurang sesuai dengan kebutuhan pengguna. Keberhasilan implementasi sistem informasi akademik salah satunya bisa dilihat dari tingkatkepuasan pengguna. Kepuasan pengguna dapat diukur dari seberapa efisien dan efekif fungsional sistem berjalan. Dalam penelitian ini dilakukan pengujian berbasis User Experience(UX) dengan menggunakan metode User Experience Quistionaire (UEQ) untukmengetahui tingkat efektivitas dari implementasi sistem informasi akademik.Metode UEQ memiliki 26 item pernyataan dengan skala 1 sampai 7 yang dikelompokkan menjadi 6komponen.Berdasarkan hasil pengujian yang dilakukan terhadap 20 responden pengguna diketahuibahwa implementasi sistem informasi akademik bisa diterima dengan baik dan dapat dimaksimalkan penggunaannya dalam prosespengolahan data akademik.
\end{abstract}

Kata kunci : akademik, pengujian, user experience (ux), userexperience quistionaire (ueq).

\section{PENDAHULUAN \\ Latarbelakang}

Pesatnya perkembangan teknologi yang ada mempengaruhi cepatnya penyebaran informasi. Informasi merupakan kunci penting bagi sebuah instansi, tak terkecuali sekolah. Dengan adanya informasi, pihak sekolah bisa mengetahui kelemahan, kekuatan, peluang, serta ancaman yang ada, sehingga mampu menentukan strategi yang tepat untuk berkembang. Mengingat pentingnya informasi bagi pihak sekolah, maka kualitas informasi harus diperhatikan dan dapat diatasi dengan penggunaan sistem informasi akademik. Salah satu sekolah yang mengalami kesulitan dalam pengelolaan data akademik yaitu Sekolah Dasar Negeri 6, seperti lambatnya proses pencarian data yang dibutuhkan, sering terjadi kesalahan dalam pengolahan data, sering terjadi kehilangan data, dan sering ditemukan data yang tidak konsisten karena media penyimpanan yang belum tersentralisasi.

Sehingga penelitian ini bertujuan untuk merancang dan membangun sistem informasi akademik berbasis web yang dapat membantu dalam proses pengolahan data akademik secara efektif serta mengimplementasikan dan melakukan pengujian sistem informasi akademik berbasiswebsite pada Sekolah Dasar Negeri 6 dengan pendekatan UserExperince (UX)

\section{Kajian Pustaka}

Meneliti pengaruh dari perbedaan kriteria individu serta pengalaman dalam menggunakan komputer terhadap penilaian kredibilitas sebuah halaman website. Kelebihan dari penelitian ini adalah dilakukan analisis terhadap fitur-fitur struktural dan fitur-fitur pesan dari sebuah 
website dengan melibatkan tiga tipe partisipan yang berbeda sesuai keahlian dalam menggunakan komputer untuk memberikan penilaian terhadap kredibilitas sebuah website. Kelemahan dari penelitian ini adalah hanya menggunakan metode pengumpulan data melalui wawancara dalam melakukan analisis kualitatif[1]. Implementasi UI/UX pada sebuahwebsite tidak hanya bergantung pada tampilan yang bagus dan indah, tetapi harus melihat sisi lain dari pengguna, apakah desain yang dibuat dapat digunakan dengan mudah bagi pengguna awam atau tidak. Kelebihan dari penelitian ini adalah implementasi UX dan UI design pada website PT. Time Excelindo dapat meningkatkan pengalaman pengguna dalam mendapatkan informasi dalam website tersebut. Kekurangan dari penelitian ini adalah kurangnya fitur-fitur yang terdapat dalam profile website PT. Time Excelindo[2].

Evaluasi terhadap sistem informasi akademik untuk mengetahui faktor yang dapat mempengaruhi keinginan pengguna dalam menggunakan sistem informasi akademik dengan pendekatan User Experience (UX). Pengukuran UX menggunakan metode framework HEART dan PULSE dan menggunakan bentuk konstruk pengukuran TAM. Kelebihan dari penelitian ini adalah dilakukan evaluasi dengan pendekatan UX sehingga bisa diketahui hal apa saja yang dirasakan pengguna ketika menggunakan sistem informasi akademik. Kekurangan dari penelitian ini yaitu terbatasnya proses pengujian UX yang hanya melibatkan sebagian tipe pengguna sistem informasi akademik tersebut[5]. Menilai bagaimana karakteristik pengalaman pengguna dari aplikasi berbasis web terkait dengan pedoman aksebilitas web dengan mengadopsi karakteristik Rubinoff. Kelebihan dari penelitian ini adalah menjelaskan keterkaitan antara aspek pengalaman pengguna dan standar aksebilitas web yang bisa dijadikan referensi untuk menghasilkan desain aplikasi berbasis web sesuai kebutuhan pengguna. Kekurangan dari penelitian ini adalah keterbatasan evaluasi terhadap web dengan menggunakan karakteristik Rubinoff[9].

Maka dilakukan penelitian untuk merancang dan membangun sistem informasi akademik berbasis website pada Sekolah Dasar Negeri 6. Sistem informasi yang dibuat bersifat multiuser sehinggabisa digunakan beberapauser dengan hak akses yang berbeda. Untuk mengetahui seberapa efektif impelementasi sistem informasi akademik tersebut maka dilakukan pengujian dengan menerapkan pendekatan User Experince (UX).

\section{Metodologi Penelitian}

Metodologi penelitian direpresentasikan pada Gambar 1. yang meliputi metode pengumpulan data dan pengujian sistem informasi akademik. Pengumpulan data meliputi observasi langsung ke lokasi sekolah, wawancara kepada pihak terkait dalam pembangunan system informasi terutama pengguna dan studi pustaka yang bersumber pada buku serta jurnal yang relevan. 


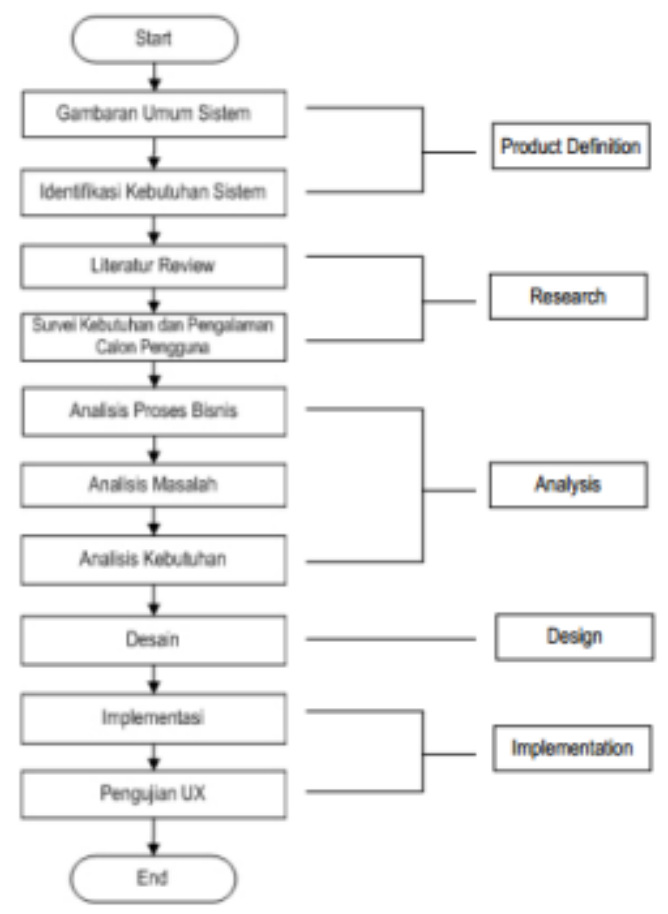

Gambar 1. Gambaran umum sistem

\subsection{User Experience (UX)}

User Experience metode yang simpel tanpa harus membuat responden berpikir lama untuk mengisi kuisioner, namun metode ini tidak dapat digunakan untuk sebuah penelitian yang memerlukan pertanyaan dengan materi yang mendalam. Tahapan UX dapat dilihat pada Gambar 2.

User Experience (UX) dapat didefinisikan sebagai segala pengalaman yang dialami oleh pengguna saat berinteraksi dengan alat digital. Konsep UX diantaranya [4]:

1. Findability, adalah aspek kemudahan dalam mencari informasi dalam suatu produk digital.

2. Accessibility, adalah kriteria kemudahan akses, seperti produk tersebut dapat diakses saat koneksi internet lemah atau dapat diakses saat dibutuhkan, serta dapat diakses dari mana saja dan kapan saja.

3. Desirability, adalah kriteria dimana ada jaminan bahwa produk tersebut diinginkan karena pengguna merasa senang saat menggunakannya.

4. Usability, adalah kriteria kemudahan penggunaan produk, semua kalangan dapat memahami produk dengan mudah.

5. Credibility, membahas kriteria kepercayaan pengguna terhadap suatu produk, termasuk keamanan data penggunaan.

6. Usefulness, merupakan kriteria adanya jaminan bahwa produk bermanfaat bagi pengguna

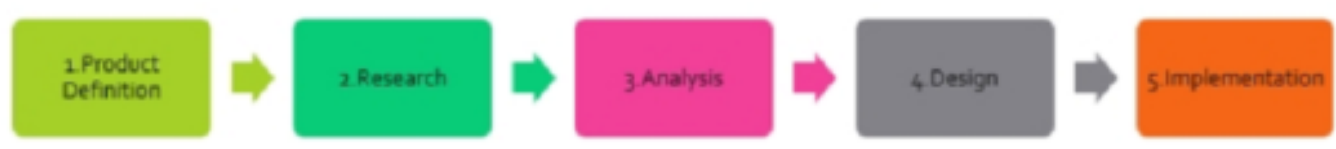

Gambar 2. Tahapan user experience

Untuk mengetahui tingkat kepuasan pengguna terhadap sistem informasi akademik yang dimplementasikan ini, maka dilakukan pengujian dengan menggunakan metode User Experince Quistionaire (UEQ) yang bertujuan untuk mendapatkan informasi mengenai kepuasan pengguna ketika berinteraksi dengan sistem informasi akademik berbasis website. 
Skala nilai antara -3 sampai -1 merepresentasikan tingkat ketidakpuasan pengguna, 0 untuk penilaian netral, dan nilai antara 1 sampai 3 merepresentasikan tingkat kepuasan pengguna

Kuisioner penelitian diberikan langsung kepada responden yaitu pengguna sistem informasi akademik berbasis web yang terdiri dari siswa, guru/wali kelas, tata usaha, dan kepal. Kuisioner terdiri dari pasangan atribut bertolak belakang secara makna yang dapat merepresentasikan produk. Contoh pengisian kuisioner untuk pengujian komponen attractiveness (daya tarik) dari sebuah produk dapat dilihat pada Gambar 3.

\begin{tabular}{|c|c|c|c|c|c|c|c|c|c|c|}
\hline \multicolumn{11}{|c|}{ Attractivonoss(daya tank) } \\
\hline \multirow[t]{7}{*}{1.} & \multicolumn{10}{|c|}{ Bagaimana tangzapan andaterhadap fitur yang tersedia serta tampilan interjace website? } \\
\hline & 1 & menyusahkan & -3 & -2 & -1 & 0 & $\mathbf{x}$ & 2 & 3 & menyenangkan \\
\hline & 2 & baik & 3 & $\mathbf{X}$ & 1 & 0 & -1 & .2 & -3 & bunuk \\
\hline & 3 & tidak disukai & -3 & -2 & -1 & 0 & $\mathbf{X}$ & 2 & 3 & menggembirakan \\
\hline & 4 & tidaknyaman & 3 & 2 & -1 & $\overline{0}$ & 1 & $\mathbf{X}$ & 3 & nyaman \\
\hline & 5 & atraktif & 3 & $X$ & 1 & 0 & -1 & -2 & -3 & tidak atraktif \\
\hline & 6 & ramahpengzina & 3 & $\mathbf{X}$ & 1 & 0 & -1 & -2 & -3 & tidak ramah penggruna \\
\hline
\end{tabular}

Gambar 3. Contoh Pengisian User Experience Quistionaire (UEQ)

Dari hasil isian kuisioner didapat rata-rata skala penilaian berdasarkan ketentuan pada tabel skala nilai UEQ sebesar 1,67 dengan perhitungan sebagai berikut:

$$
\frac{1+2+1+2+2+2}{6}=1,67
$$

Berdasarkan hasil yang didapat tersebut disimpulkan bahwa produk yang dievaluasi oleh responden memiliki daya tarik yang bagus karena berada dalam rentang nilai antara 1 sampai 3. Perhitungan tersebut juga berlaku untuk pengujian lima komponen lainnya dalam kuisioner UEQ.

\section{Perancangan procedural}

Perancangan sistem merupakan tahap lanjutan dari analisis sistem, dimana pada perancangan sistem digambarkan rancangan sistem yang akan dibangun sebelum melakukan pengkodean ke dalam suatu bahasa pemograman.

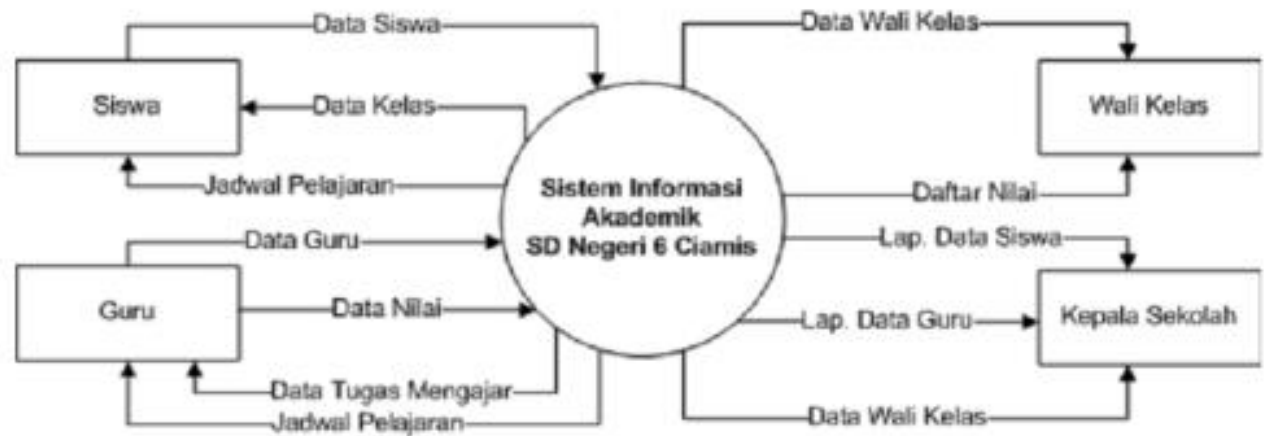

Gambar 4. Diagram konteks 


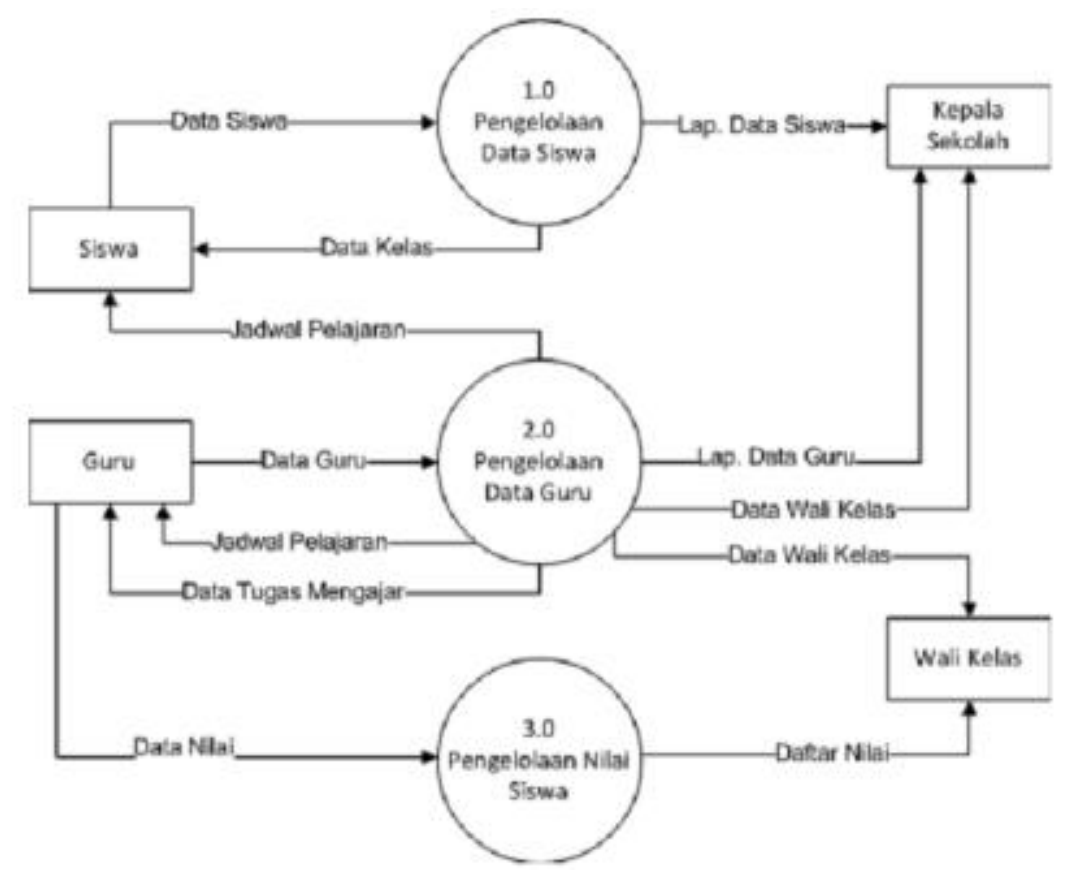

Gambar 5. Diagram Flow diagram level 1

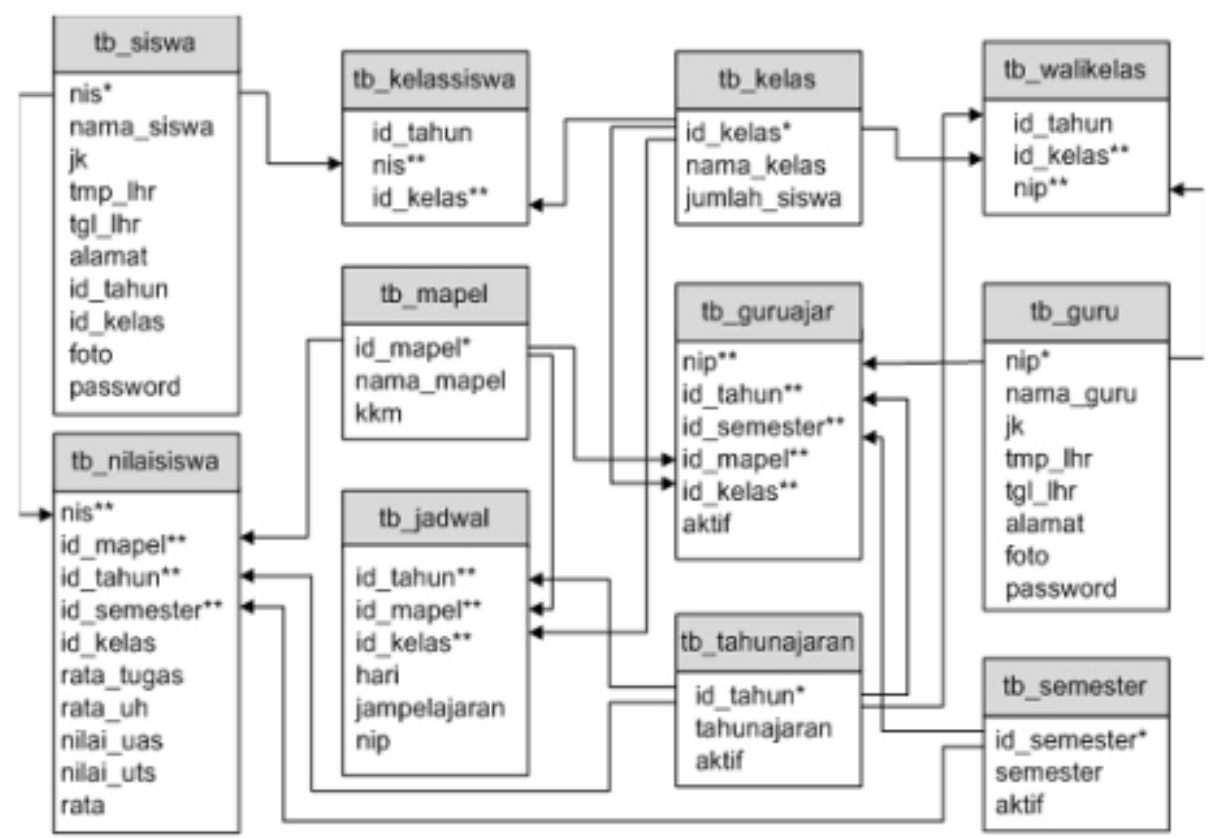

Gambar 6. Diagram relasi tabel

\subsection{Perancangan Arsitektur sistem}




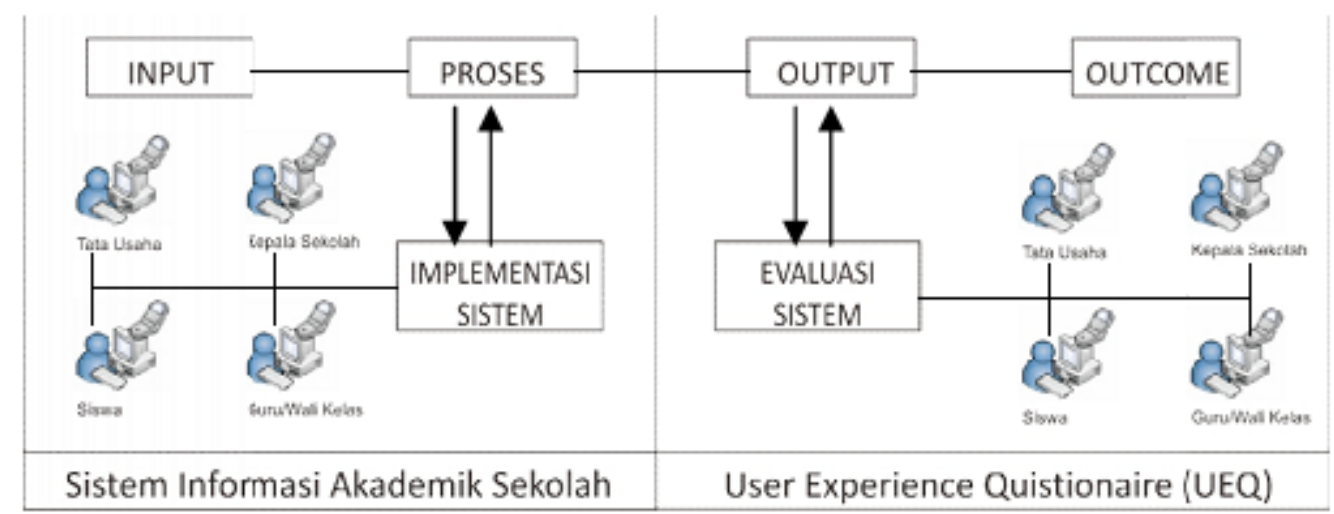

Gambar 7. Perancangan Arsitektur sistem

\subsection{Hasil dan Pembahasan}

Penelitian ini fokus pada pembahasan tentang pengujian pengguna. Namun pengujian sistem juga dilakukan dengan tujuan untuk menguji beberapa element perangkat lunak yang dibuat apakah sudah sesuai dengan yang diharapkan atau belum. Tujuan dari pengujian perangkat lunak adalah untuk menjamin perangkat lunak yang dibangun memiliki kualitas yang baik dan handal.

\subsection{Pengujian Pengguna}

Pengolahan data akademik berdasarkanpendekatan UX denganmenggunakan metode UEQ. Pengujian pengguna dilakukan dengan menyebarkan kuisioner kepada pengguna sistem informasi akademik sekolah dasar negeri 6 ciamis yang terdiri dari 1 responden Kepala Sekolah, 8 responden guru/wali kelas, 1 responden tata usaha, dan 10 responden siswa. Setiap responden diminta mengisi kuisioner yang terdiri dari 26 pernyataan/pertanyaan yang dikelompokkan menjadi 6 komponen untuk mengevaluasi website sistem informasi akademik dengan caramemilih lingkaran setiap item kuisioner dari skala 1 sampai 7 yang merepresentasikan gradasi antar atribut yang bertolak belakang. 
Tabel 1. Data Hasil Pengisian Kuisioner

\begin{tabular}{|c|c|c|c|c|c|c|c|c|c|c|c|c|c|c|c|c|c|c|c|c|c|c|c|c|c|c|}
\hline \multirow{2}{*}{ No } & \multicolumn{26}{|c|}{ Items UEQ } \\
\hline & 1 & 2 & 3 & 4 & 5 & 6 & 7 & 8 & 9 & 10 & 11 & 12 & 13 & 14 & 15 & 16 & 17 & 18 & 19 & 20 & 21 & 22 & 23 & 24 & 25 & 26 \\
\hline rl & 6 & 1 & 6 & 7 & 3 & 2 & 1 & 6 & 6 & 2 & 6 & 3 & 7 & 2 & 4 & 6 & 3 & 2 & 2 & 3 & 4 & 5 & 1 & 5 & 6 & 3 \\
\hline $\mathrm{r} 2$ & 6 & 2 & 5 & 6 & 3 & 3 & 1 & 5 & 5 & 3 & 5 & 3 & 6 & 3 & 4 & 6 & 4 & 2 & 3 & 4 & 5 & 6 & 2 & 4 & 6 & 2 \\
\hline$r 3$ & 5 & 2 & 5 & 5 & 2 & 3 & 2 & 5 & 5 & 3 & 5 & 3 & 7 & 2 & 4 & 6 & 4 & 2 & 2 & 4 & 5 & 6 & 2 & 4 & 5 & 3 \\
\hline $\mathrm{r} 4$ & 5 & 2 & 5 & 4 & 2 & 2 & 1 & 5 & 5 & 2 & 6 & 2 & 7 & 2 & 3 & 6 & 4 & 2 & 2 & 4 & 4 & 5 & 2 & 4 & 4 & 3 \\
\hline r5 & 6 & 2 & 5 & 6 & 3 & 3 & 1 & 6 & 5 & 2 & 4 & 2 & 7 & 2 & 5 & 6 & 3 & 3 & 2 & 3 & 5 & 5 & 1 & 3 & 5 & 2 \\
\hline r6 & 4 & 2 & 5 & 6 & 3 & 3 & 2 & 5 & 5 & 3 & 4 & 3 & 6 & 3 & 4 & 6 & 4 & 2 & 3 & 3 & 5 & 6 & 1 & 2 & 5 & 2 \\
\hline r7 & 5 & 2 & 5 & 5 & 3 & 2 & 1 & 5 & 6 & 3 & 6 & 3 & 6 & 2 & 5 & 6 & 3 & 2 & 2 & 4 & 5 & 6 & 2 & 3 & 5 & 3 \\
\hline r8 & 6 & 2 & 6 & 5 & 3 & 2 & 1 & 6 & 5 & 2 & 5 & 3 & 7 & 2 & 3 & 6 & 4 & 2 & 2 & 3 & 5 & 5 & 2 & 5 & 5 & 2 \\
\hline $\mathrm{r} 9$ & 5 & 1 & 5 & 6 & 3 & 3 & 2 & 5 & 6 & 2 & 5 & 3 & 6 & 2 & 6 & 6 & 4 & 3 & 2 & 3 & 5 & 5 & 2 & 5 & 6 & 2 \\
\hline rlo & 5 & 1 & 6 & 7 & 2 & 2 & 1 & 5 & 6 & 2 & 7 & 3 & 7 & 1 & 6 & 6 & 3 & 2 & 2 & 3 & 6 & 5 & 1 & 5 & 6 & 2 \\
\hline rll & 5 & 3 & 4 & 5 & 4 & 3 & 1 & 6 & 4 & 3 & 5 & 4 & 5 & 2 & 4 & 5 & 4 & 3 & 3 & 4 & 3 & 4 & 3 & 3 & 5 & 3 \\
\hline rl2 & 6 & 2 & 3 & 5 & 3 & 3 & 1 & 6 & 5 & 2 & 5 & 4 & 6 & 3 & 3 & 5 & 4 & 3 & 3 & 4 & 4 & 5 & 3 & 3 & 5 & 3 \\
\hline r13 & 4 & 2 & 5 & 4 & 2 & 3 & 2 & 4 & 5 & 3 & 4 & 4 & 5 & 3 & 5 & 5 & 4 & 3 & 3 & 4 & 4 & 4 & 3 & 3 & 4 & 3 \\
\hline rl4 & 5 & 3 & 6 & 5 & 3 & 2 & 2 & 5 & 5 & 2 & 5 & 3 & 5 & 3 & 4 & 5 & 3 & 2 & 3 & 3 & 3 & 3 & 2 & 3 & 5 & 4 \\
\hline r15 & 3 & 3 & 5 & 5 & 3 & 3 & 1 & 6 & 5 & 2 & 4 & 3 & 6 & 3 & 4 & 5 & 3 & 3 & 3 & 2 & 5 & 5 & 3 & 4 & 5 & 4 \\
\hline r16 & 4 & 2 & 4 & 5 & 4 & 2 & 1 & 6 & 4 & 3 & 5 & 4 & 4 & 2 & 4 & 5 & 3 & 2 & 3 & 4 & 4 & 3 & 3 & 4 & 4 & 3 \\
\hline rl7 & 5 & 2 & 5 & 4 & 2 & 2 & 1 & 5 & 6 & 3 & 5 & 3 & 5 & 2 & 4 & 5 & 4 & 3 & 2 & 4 & 6 & 6 & 3 & 5 & 5 & 4 \\
\hline rl8 & 4 & 3 & 5 & 4 & 2 & 3 & 2 & 6 & 5 & 2 & 6 & 3 & 5 & 3 & 4 & 5 & 3 & 4 & 3 & 3 & 5 & 5 & 3 & 5 & 5 & 3 \\
\hline r19 & 3 & 3 & 4 & 6 & 3 & 2 & 1 & 5 & 5 & 3 & 5 & 3 & 5 & 3 & 4 & 5 & 3 & 2 & 3 & 3 & 5 & 4 & 2 & 4 & 5 & 3 \\
\hline $\mathrm{r} 20$ & 4 & 2 & 6 & 5 & 3 & 3 & 2 & 5 & 4 & 2 & 5 & 3 & 6 & 3 & 5 & 5 & 4 & 3 & 5 & 3 & 4 & 4 & 3 & 4 & 5 & 4 \\
\hline
\end{tabular}

Keterangan:

r1 - r20 = Responden ke 1 - Responden ke 20

Hasil isian kuisioner jika dikonversikan ke dalam skala nilai antara -3 sampai -1 yang merepresentasikan penilaian buruk, nilai 0 merepresentasikan penilaian netral, dan nilai antara 1 sampai 3 merepresentasikan penilaian baik seperti ketentuan yang terdapat pada tabel skala UEQ, maka diperoleh data nilai seperti yang terlihat pada tabel 2. 


\begin{tabular}{|c|c|c|c|c|c|c|c|c|c|c|c|c|c|c|c|c|c|c|c|c|c|c|c|c|c|c|c|}
\hline \multirow{2}{*}{ No } & \multicolumn{27}{|c|}{ Items UEQ } \\
\hline & 1 & 2 & 3 & 4 & 5 & 6 & 7 & 8 & 9 & 10 & 11 & 12 & 13 & 14 & 15 & 16 & 17 & 18 & 19 & 20 & & 21 & 22 & 23 & 24 & 25 & 26 \\
\hline $\mathrm{rl}$ & 2 & 3 & 2 & 3 & 1 & 2 & 3 & 2 & 2 & 2 & 2 & 1 & 3 & 2 & 0 & 2 & 1 & 2 & 2 & 1 & & 0 & 1 & 3 & 1 & 2 & 1 \\
\hline r2 & 2 & 2 & 1 & 2 & 1 & 1 & 3 & 1 & 1 & 1 & 1 & 1 & 2 & 1 & 0 & 2 & 0 & 2 & 1 & 0 & & 1 & 2 & 2 & 0 & 2 & 2 \\
\hline $\mathrm{r} 3$ & 1 & 2 & 1 & 1 & 2 & 1 & 2 & 1 & 1 & 1 & 1 & 1 & 3 & 2 & 0 & 2 & 0 & 2 & 2 & 0 & & 1 & 2 & 2 & 0 & 1 & 1 \\
\hline $\mathrm{r} 4$ & 1 & 2 & 1 & 0 & 2 & 2 & 3 & 1 & 1 & 2 & 2 & 2 & 3 & 2 & -1 & 2 & 0 & 2 & 2 & 0 & & 0 & 1 & 2 & 0 & 0 & 1 \\
\hline $\mathrm{r} 5$ & 2 & 2 & 1 & 2 & 1 & 1 & 3 & 2 & 1 & 2 & 0 & 2 & 3 & 2 & 1 & 2 & 1 & 1 & 2 & 1 & & 1 & 1 & 3 & -1 & 1 & 2 \\
\hline r6 & 0 & 2 & 1 & 2 & 1 & 1 & 2 & 1 & 1 & 1 & 0 & 1 & 2 & 1 & 0 & 2 & 0 & 2 & T & 1 & & 1 & 2 & 3 & -2 & 1 & 2 \\
\hline r7 & 1 & 2 & 1 & 1 & 1 & 2 & 3 & 1 & 2 & 1 & 2 & 1 & 2 & 2 & 1 & 2 & 1 & 2 & 2 & 0 & & 1 & 2 & 2 & -1 & 1 & 1 \\
\hline $\mathrm{r} 8$ & 2 & 2 & 2 & 1 & 1 & 2 & 3 & 2 & 1 & 2 & 1 & 1 & 3 & 2 & -1 & 2 & 0 & 2 & 2 & 1 & & 1 & 1 & 2 & 1 & 1 & 2 \\
\hline r9 & 1 & 3 & 1 & 2 & 1 & 1 & 2 & 1 & 2 & 2 & 1 & 1 & 2 & 2 & 2 & 2 & 0 & 1 & 2 & 1 & & 1 & 1 & 2 & 1 & 2 & 2 \\
\hline $\mathrm{r} 10$ & 1 & 3 & 2 & 3 & 2 & 2 & 3 & 1 & 2 & 2 & 3 & 1 & 3 & 3 & 2 & 2 & 1 & 2 & 2 & 1 & & 2 & 1 & 3 & 1 & 2 & 2 \\
\hline $\mathrm{rll}$ & 1 & 1 & 0 & 1 & 0 & 1 & 3 & 2 & 0 & 1 & 1 & 0 & 1 & 2 & 0 & 1 & 0 & 1 & 1 & 0 & - & -1 & 0 & 1 & -1 & 1 & 1 \\
\hline $\mathrm{rl2}$ & 2 & 2 & -1 & 1 & 1 & 1 & 3 & 2 & 1 & 2 & 1 & 0 & 2 & 1 & -1 & 1 & 0 & 1 & 1 & 0 & & 0 & 1 & 1 & -1 & 1 & 1 \\
\hline $\mathrm{rl3}$ & 0 & 2 & 1 & 0 & 2 & 1 & 2 & 0 & 1 & 1 & 0 & 0 & 1 & 1 & 1 & 1 & 0 & 1 & 1 & 0 & & 0 & 0 & 1 & -1 & 0 & 1 \\
\hline $\mathrm{rl4}$ & 1 & 1 & 2 & 1 & 1 & 2 & 2 & 1 & 1 & 2 & 1 & 1 & 1 & 1 & 0 & 1 & 1 & 2 & 1 & 1 & & -1 & -1 & 2 & -1 & 1 & 0 \\
\hline $\mathrm{rl5}$ & -1 & 1 & 1 & 1 & 1 & 1 & 3 & 2 & 1 & 2 & 0 & 1 & 2 & 1 & 0 & 1 & 1 & 1 & 1 & 2 & & 1 & 1 & 1 & 0 & 1 & 0 \\
\hline r16 & 0 & 2 & 0 & 1 & 0 & 2 & 3 & 2 & 0 & 1 & 1 & 0 & 0 & 2 & 0 & 1 & 1 & 2 & 1 & 0 & & 0 & -1 & 1 & 0 & 0 & 1 \\
\hline $\mathrm{r} 17$ & 1 & 2 & 1 & 0 & 2 & 2 & 3 & 1 & 2 & 1 & 1 & 1 & 1 & 2 & 0 & 1 & 0 & 1 & 2 & 0 & & 2 & 2 & 1 & 1 & 1 & 0 \\
\hline r18 & 0 & 1 & 1 & 0 & 2 & 1 & 2 & 2 & 1 & 2 & 2 & 1 & 1 & 1 & 0 & 1 & 1 & 0 & 1 & 1 & & 1 & 1 & 1 & 1 & 1 & 1 \\
\hline r19 & -1 & 1 & 0 & 2 & 1 & 2 & 3 & 1 & 1 & 1 & 1 & 1 & 1 & 1 & 0 & 1 & 1 & 2 & 1 & 1 & & 1 & 0 & 2 & 0 & 1 & 1 \\
\hline $\mathrm{r} 20$ & \begin{tabular}{|l|}
0 \\
\end{tabular} & 2 & 2 & 1 & 1 & 1 & 2 & 1 & 0 & 2 & 1 & 1 & 2 & 1 & 1 & 1 & 0 & 1 & -1 & 1 & ( & 0 & 0 & 1 & 0 & 1 & 0 \\
\hline
\end{tabular}

Dari hasil konversi skala nilai item UEQ, maka didapat skala nilai rata-rata keenam komponen UEQ dari setiap responden seperti terlihat pada tabel 3.

Tabel 5. Rata-rata Skala Nilai Komponen UEQ

\begin{tabular}{|l|c|}
\hline \multicolumn{2}{|c|}{ UEQ Scales } \\
\hline Daya tarik & 1.267 \\
\hline Kejelasan & 1.375 \\
\hline Efisiensi & 1.663 \\
\hline Ketepatan & 0.925 \\
\hline Stimulasi & 0.963 \\
\hline Kebaruan & 0.850 \\
\hline
\end{tabular}


Tabel 6. Rata-rata Skala Nilai Per-Responden

\begin{tabular}{|c|c|c|c|c|c|c|}
\hline \multirow{2}{*}{ No } & \multicolumn{6}{|c|}{ Rata-rata Skala Per-Responden } \\
\hline & Daya tarik & Kejelasan & Efisiensi & Ketepatan & Stimulasi & Kebaruan \\
\hline $\mathrm{rl}$ & 2.17 & 2.00 & 2.25 & 1.25 & 1.75 & 1.00 \\
\hline $\mathrm{r} 2$ & 1.50 & 1.25 & 1.50 & 1.00 & 1.50 & 1.00 \\
\hline $\mathrm{r} 3$ & 1.33 & 1.75 & 1.25 & 1.00 & 1.00 & 1.25 \\
\hline $\mathrm{r} 4$ & 1.33 & 2.25 & 1.75 & 0.75 & 0.75 & 0.75 \\
\hline $\mathrm{r} 5$ & 1.50 & 1.75 & 2.00 & 1.25 & 1.25 & 1.25 \\
\hline r6 & 1.17 & 1.00 & 1.25 & 1.00 & 1.00 & 1.25 \\
\hline r7 & 1.33 & 1.75 & 1.75 & 1.50 & 0.75 & 1.25 \\
\hline r8 & 1.67 & 1.75 & 2.00 & 0.75 & 1.50 & 1.25 \\
\hline r9 & 1.50 & 1.50 & 1.75 & 1.25 & 1.75 & 1.25 \\
\hline $\mathrm{r} 10$ & 2.17 & 2.50 & 2.00 & 1.75 & 2.00 & 1.50 \\
\hline rl1 & 0.67 & 1.00 & 1.50 & 0.50 & 0.50 & 0.00 \\
\hline r12 & 1.00 & 1.00 & 2.00 & 0.25 & 0.50 & 0.50 \\
\hline r13 & 1.00 & 0.50 & 1.00 & 0.75 & 0.25 & 0.25 \\
\hline rl4 & 1.33 & 1.00 & 1.50 & 1.00 & 0.50 & 0.00 \\
\hline r15 & 0.67 & 1.00 & 2.00 & 0.75 & 0.50 & 1.25 \\
\hline r16 & 0.83 & 0.75 & 1.50 & 1.00 & 0.50 & 0.00 \\
\hline r17 & 1.33 & 1.25 & 1.75 & 0.50 & 0.75 & 1.50 \\
\hline r18 & 0.83 & 1.25 & 1.75 & 0.50 & 1.00 & 1.00 \\
\hline r19 & 0.83 & 1.00 & 1.50 & 1.00 & 1.00 & 0.75 \\
\hline $\mathrm{r} 20$ & 1.17 & 1.25 & 1.25 & 0.75 & 0.50 & 0.00 \\
\hline
\end{tabular}

Rata-rata skala nilai komponen UEQ dikonversikan ke dalam bentuk grafik sehingga dapat diketahui hasil dari evaluasi terhadap Sistem Inhalamanasi Akademik Sekolah Dasar Negeri 6 termasuk kategori Excellent, Good, Above Average, Below Average, atau Bad seperti terlihat pada Gambar 4.

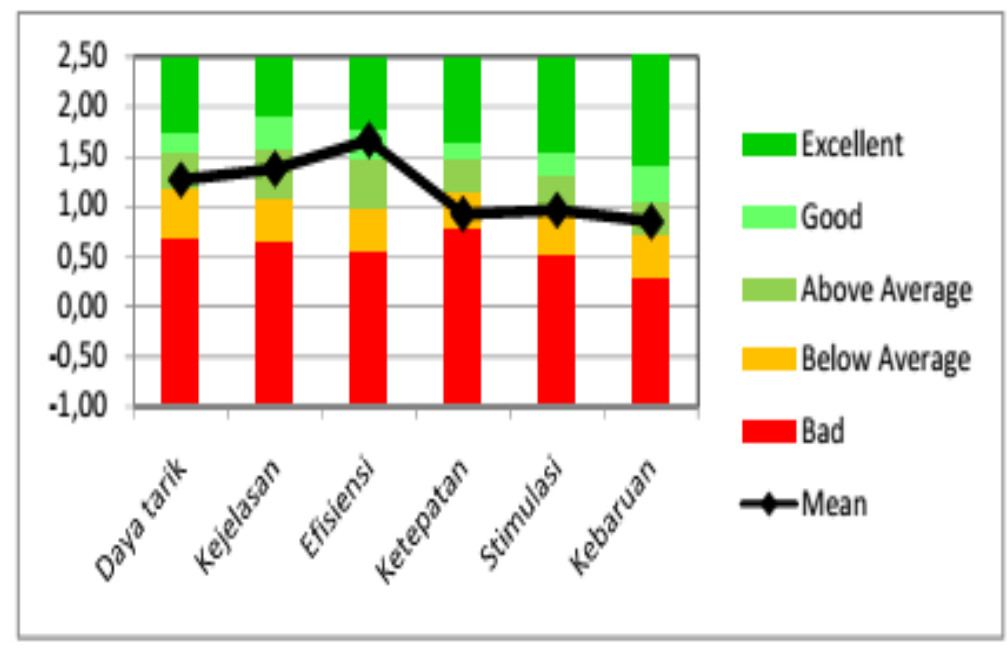

Gambar 8.Grafik Hasil Pengisian UEQ

\section{Kesimpulan}

Berdasarkan hasil pengujian terhadap sampel pengguna yang terdiri dari 20 responden dapat disimpulkan bahwa implementasi sistem informasi akademik pada Sekolah Dasar Negeri 6 bisa diterima dengan baik dan dapat dimaksimalkan penggunaannya oleh Kepala 
Sekolah, guru/wali kelas, tata usaha, dan siswa dalam pengolahan data akademik. Akan tetapi masih terdapat beberapa komponen yang dinilai perlu pengembangan lebih lanjut yaitu komponen ketepatan dan stimulasi. Dengan adanya sistem informasi akademik berbasis website pada Sekolah Dasar Negeri 6 dapat memberi kemudahan bagi pengguna dalam melakukan proses pengolahan data akademik sehingga lebih akurat, efektif, dan tepat waktu.

\section{Daftar Pustaka}

[1] Departemen Pendidikan Nasional. 2005. Kamus Besar BahasaIndonesia Edisi Ke 3. Jakarta: Balai Pustaka.

[2] Lawrence, David. Pengertian,Implementasi, dan PemanfaatanUser Experience dalam BidangTIK.Mhs.blog.ui.ac.id. https://mhs.blog.ui.ac.id/david.lawrence/2016/04/04/pengert ian-implementasidanpemanfaatan-user-experiencedalam-bidang-tik/ (diakses pada 10 Oktober 2016).

[3] Lestari, P.N., dan Paulus Insap Santosa, 2016, PengukuranPengalaman Pengguna Dalam Menggunakan Sistem InformasiAkademik, Seminar Nasional Teknologi Informasi dan Komunikasi 2016 (SENTIKA 2016), 136-143, ISSN: 2089-9815.

[4] Mustakini, Jogiyanto Hartono. 2009. Sistem Informasi Teknologi. Yogyakarta: Andi Offset.

[5]Setiawan, Iwan. Sekilas TentangUser Experience. Intraktive.com. http://www.intraktive.com/article/9 9-sekilas-tentang-userexperience.html (diakses pada 10 Oktober 2016).

[6] Sugiarti, D., 2012, Sistem InformasiAkademik Sekolah Dasar AlMuhajirin Barehan Sidoharjo

Pacitan, Journal Speed - Sentra Penelitian Engineering dan Edukasi 4 (1), 18-27, ISSN : 1979-9330.

[7]Trisnio, Kevin. User ExperienceDesign Process. Sis.binus.ac.id. http://sis.binus.ac.id/2016/07/29/us er-experience-design-process (diakses pada 10 Oktober 2016).

[8] Yakub. 2012. Pengantar SistemInformasi. Yogyakarta: Graha Ilmu. 